\title{
Caimans and Crocodiles - a Tale of Destruction
}

\author{
Federico Medem
}

In Latin America crocodilians are being poached and smuggled in thousands every year for their skins, and their future is bleak. Dr Medem, who is Colombia's foremost conservationist and reptile specialist, believes that only international efforts can save the caimans and crocodiles and that first Colombia must be persuaded to join the CITES Convention.

In the $2 \frac{1}{2}$ years from January 1976 to June $19781,180,153$ caiman hides were legally exported from Colombia, according to official figures which Alberto Donadio and I have extracted from the export registers. This is the absolute minimum. It takes no account of illegal trade or discrepancies in the files, and Fittkau has shown it is safe to assume that for every hide counted one or two can be added. So the figure could exceed two million.

It is not known where all these hides come from - certainly not all from Colombia. One dealer in Manaus, Brazil, pays US\$10-26 for a hide, depending on its size. In October or November 1978 a shipment of 400,000 was said to be on its way from Manaus to Leticia, in extreme southern Colombia, and from there via Aruba, Netherlands Antilles, to West Germany (presumably to Offenbach, the centre of the German leather industry).

Hides are also smuggled from Venezuela along the Meta river, which forms part of the border, and up a Colombian tributary of the Meta, the Casanare. Settlers in the Orinoco plains, the Llanos, which span both countries, are eager to hunt as much as they can because of the high prices offered: at one time $\$ 6.25$ was the price for an adult $1.2 \mathrm{~m}$ skin at Puerto Lopez in the Llanos. But judging by a police seizure of 1500 smuggled skins in February 1979, the vast majority of which were only $30-60 \mathrm{~cm}$, adults may have been virtually wiped out in large areas of the Llanos.

Caimans are also hunted, illegally, along the Colombian coast between Cienaga Grande and the Magdalena river, and here, too, most of the hides are from hatchlings and juveniles; $15-25$ cents is paid for a $20-25 \mathrm{~cm}$ skin in Barranquilla, and many of these Colombian skins, as Donadio revealed in 1978, are smuggled to Panama to be re-imported legally by Colombian processors. Moreover many habitats in the Magdalena region, including the officially protected mangroves in the Isla de Salamanca National Park, have been destroyed. Despite this, some caimans manage to survive in the many lagoons along the lower and middle Magdalena valley, finding protection in vegetation that has become more abundant with the dẹcline in manatees.

\section{Crocodiles}

INDERENA, the Government conservation agency, maintains 30 American crocodiles Crocodylus acutus ( 3 adults and 27 juveniles) at the Los Cocos station on Salamanca Island, but the breeding programme has yet to succeed: eggs laid in 1977 and 1978 did not hatch. At Cienaga Grande some Caiman crocodilus fuscus at a management station were stolen by local residents, who sold them in Barranquilla, and the rest escaped during a flood. Villavicencio's Roberto Franco station keeps seven Crocodylus intermedius ranging from $50 \mathrm{~cm}$ to $3 \mathrm{~m}$ 
and including two $1.8 \mathrm{~m}$ juvenile females but no adult females. All attempts to find adult females in the wild have failed, and neither local residents, INDERENA inspectors, nor Peace Corps biologists have reported recent sightings of adult crocodiles of either sex.

From, Peru, Dr Antonio Brack-Egg, Sub-Director of Conservation of Fauna for the Ministry of Agriculture, reports that $C$. acutus near Tumbes on the north coast are diminishing rapidly because of hunting and habitat destruction. Most of the mangroves have been cut down, and crocodiles remain only in isolated groups at the northern border of the Parque Nacional Cerros de Amotape, in the Cañon de Ucumares on the Tumbes river. This small canyon is inaccessible and therefore safe for the crocodiles, but can only accommodate a few, and without an effective guard even their survival cannot be guaranteed. Moreover the large breeding animals migrate annually to the mangrove zone along the coast. On the Chira river north of Piura C. acutus has been totally exterminated.

\section{Colombia and CITES}

The future of crocodilians in Latin America is bleak, and there is a severe gap in our monitoring system due to a lack of interested and qualified people in the field. Thus we are in the frustrating position of having to witness a massive slaughter while being virtually unable to pinpoint its perpetrators. What is needed is a multilateral international effort that must begin with Colombian acceptance of the CITES Convention.

The export statistics compiled by Dr Medem and Alberto Donadio have been published in the TRAFFIC Bulletin, obtainable from TRAFFIC, 1 Marshall Street, London W1.

\section{Captive Breeding for Plants}

The Threatened Plants Group (TPC) of IUCN is using botanic gardens as the spearhead of its attack - both in discovering what plants they are growing and increasingly to supply the demand for rare plants and save collection in the wild. Gren Lucas, Chairman of TPC, points out that 'captive breeding' is much more applicable for plants than most mammals, and if enough can be supplied to meet the demand it will take the pressure off the wild populations particularly important with desirable species like orchids and cacti. An Earthscan report has described how, a few years ago, cactus 'rustling' became serious in Arizona:

'Drought-stricken home developers turned to cactus plants for landscaping their gardens, and the plants became so popular that demand exceeded supply and a black market developed. Rustlers stole cacti, Joshua trees and yuccas, some of which may have taken a century to grow. A 20 - $\mathrm{ft}$ saguaro cactus cost up to $\$ 1000$ in San Francisco. Strict protection laws existed in Arizona but permits were easy to get and the law difficult to enforce. In 1977 California followed Arizona with legislation, as the problem spread to other states. More than 60,000 cacti per year were harvested legally in Arizona in 1977, but a further 20,000 were poached. This over-exploitation is beginning to cause severe soil damage and erosion . . .

'The 1976 UK CITES report showed that 17,000 orchids of 160 genera were licensed for import from Madagascar, the Philippines, Guatemala, Colombia, Brazil, Mexico and Thailand. Many of these may have been propagated, but some species were certainly habitat-collected and protected in their country of origin.' 


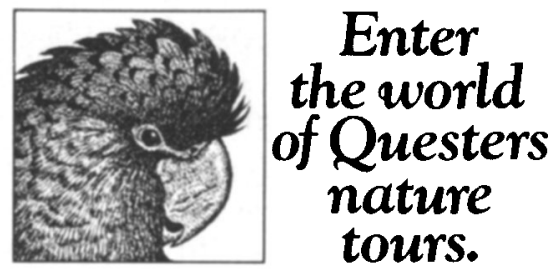

When you travel with Questers, you have the advantage of our knowledge of the travel world And our experience of the natural world. We are travel professionals. And our only tour program is Worldwide Nature Tours.

Under the leadership of an accompanying naturalist, we search out the plants and animals, birds and flowers ... rain forests, mountains, and tundra...seashores, lakes, and swamps of the regions we explore. At the same time, we include the more usual attractions in touring-the cities, archaeological sites, and people

The current Directory of Worldwide Nature Tours describes 29 tours varying from 9 to 36 days and going to virtually every part of the world. Included are The Amazon, Peru, Patagonia, Galapagos, Hawaii, Alaska, Death Valley, Everglades, Ladakh. Sri Lanka, Iceland. Scotland, Greece, Australia, and New Zealand. Tour parties are small, the pace leisurely, and itineraries unusual.

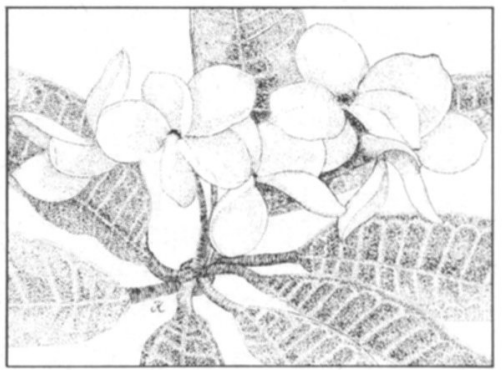

Call or write Questers or see your Travel Agent today for your free copy of the Directory of Worldwide Nature Tours.

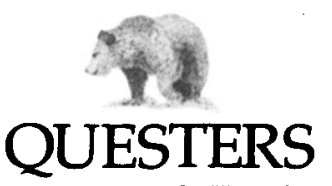

Questers Tours \& Travel, Inc.

Dept. OR, 257 Park Avenue South

N.Y., N.Y. 10010, U.S.A. • (212) $673-3120$ 